\title{
Geometrical Consideration of the Crystallography of Interphase Interfaces
}

\author{
Masaharu KАTO
}

\section{1. はじめに}

二つの異なる結晶がシャープな界面を形成する場会, 二結晶の間に特別な方位関係が存在することがよく ある.たとえば, f. c. c. 結晶と b. c. c. 結晶の間には Kurdjumov-Sachs (KS) ${ }^{1)}$ や Nishiyama-Wassermann $(\mathrm{NW})^{2) 3)}$ の方位関係がしばしば観察される。しかし, 与えられた二結晶間になぜそのような特別な方位関係が 実現するのかを理解することは, 必ずしも容易ではない.

異相界面の結晶学には, 幾何学的に説明できるものと できないものの二通りがあるとよく言われる．本解説で は当然説明できる界面を扱う。しかも，後述するように 非常に簡単な場合のみを対象とする。より複雑な界面を 取り扱わない理由は二つある。一つは筆者の理解のレべ ルを超えているためであり，もう一つはすでに立派な解 説がある(4) 8)ためである.「単純すぎる」という読者の 批判は覚悟の上であるが，それでも使えることもあると 感じていただければ有り難い。

\section{2. 幾何学的に好都合な界面}

界面の結晶学を幾何学的に考察する理論の一つに, BOLLMANN のO 格子理論 ${ }^{9}$ がある. 一般に, あるべクト ル $\boldsymbol{x}$ は $3 \times 3$ アフィン変換行列 $\boldsymbol{A}$ によって,

$$
\boldsymbol{y}=\boldsymbol{A} \boldsymbol{x}
$$

のように別のべクトル $\boldsymbol{y}$ に変換される．特に，界面を 構成する二つの結晶格子 1,2 を考え， $\boldsymbol{A}$ を格子 1 から 格子 2 への変換を表す行列，Iを単位行列とするとき, 次式で $\mathrm{O}$ 格子ベクトル $\boldsymbol{X}^{(O)}$ が定義できるという.

$\left(I-A^{-1}\right) X^{(O)}=b^{(L)}$

ここで, $A^{-1}$ は $A$ の逆行列, $\boldsymbol{b}^{(L)}$ は格子 1 の任意の並 進べクトルである. $(2)$ 式は， $\boldsymbol{X}^{(O)}$ の三つの成分を求 める三元一次連立方程式である.

二つの結晶格子面で形成される界面の幾何学的な対
応性は, $I-A^{-1}$ の行列式の絶対值, すなわち, | det

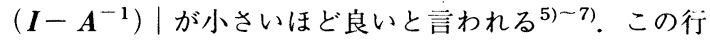
列は $3 \times 3$ 行列なので, その階数 $r$ は $0,1,2,3$ のい ずれかである. $r=3$ のときは，与えられた $b^{(L)}$ に対し て $\boldsymbol{X}^{(O)}$ はユニークに決まるので, $\mathrm{O}$ 格子点が定義でき る. 一方, 線形代数学でよく知られているように, $r \neq$ 3 なら $\left|\operatorname{det}\left(\boldsymbol{I}-\boldsymbol{A}^{-1}\right)\right|$ の值は最小値のゼロをとるの で，幾何学的には都合の良い界面ということになる．本 解説ではこのような特別な場合を主に考える。ただし， $r=0$ のときは, $\boldsymbol{A}=\boldsymbol{I}$ であり, 界面が存在しない $(\boldsymbol{A}$ は不変体変形を表す) ので興味の対象から外し, $r=1$ と $r=2$ の場合を議論する.

\section{3. $r=1$ で記述される界面 (不変面変形)}

$r=1$ のときは ( 2 ) の連立方程式のうち独立な式は ただ一つなので, 一般に $\boldsymbol{X}^{(O)}$ の解は平面を表す9). 以 下では, $x_{1}-x_{2}-x_{3}$ 右手直交座標系を基底にとる。もし, 行列 $\boldsymbol{A}$ が次式のような形のとき, $I-A^{-1}$ の階数が 1 となることはすぐわかる.

$$
\boldsymbol{A}=\left(\begin{array}{ccc}
1 & 0 & A_{13} \\
0 & 1 & A_{23} \\
0 & 0 & 1+A_{33}
\end{array}\right)
$$

図 1 に示すように,この変換行列は一般に $x_{3}$ 軸に垂直 な面（ $x_{3}$ 面）を不変面とする不変面変形を表す．特に， $A_{33}=0$ ならば単純せん断変形となる.

不変面変形を前提とする結晶学的理論の代表的なもの に, いわゆるマルテンサイト変態の現象論1011)がある. この理論では, 板状マルテンサイトと母相との界面 (晶 癖面）が不変面, すなわち, 無歪み・無回転面となるよ うにマルテンサイトの形態や結晶学が決まると考えてい る.この完成された理論はマルテンサイトに対してのみ ならず,析出物の結晶学を論じる際にも適用されている.

一般に，母相の結晶格子をマルテンサイトの結晶格子

平成 3 年 7 月 19 H受付 (Received July 19, 1991)（依頼解説）

* 束京工業大学大学院総命理工学研究科助教授 工博 (Graduate School of Science and Engineering at Nagatsuda, Tokyo Institute of Technology, 4259 Nagatsuda Midori-Ku Yokohama 227)

Key words : interface; crystallography ; geometry ; lattice correspondence ; orientation relationship ; invariant plane; invariant line; martensitic transformation; thin film; epitaxy. 


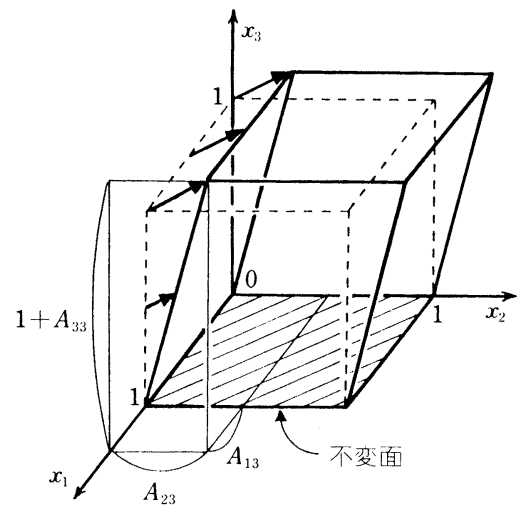

図 $1 \quad x_{3}$ 面を不変面とする不変面変形

に変換する格子変形 (たとえば Bain 変形) B のみでは 不変面変形条件を満たすことができないので，格子不変 変形（双晶またはすべりによる） $\boldsymbol{P}$ と㴊体回転 $\boldsymbol{R}$ を加 えて, マルテンサイトの全形状変形を表す変換行列 $\boldsymbol{A}$ は

$$
\boldsymbol{A}=\boldsymbol{R B P}
$$

のように三つの行列の積の形で表されると考える.ここ で，Bはマルテンサイトと相との格子対忠を使走す れば, 両相の格子定数より決まる既知の行列である，P では，双晶系 (またはすべり系)は与えられる（既知） が，互いに双晶関係にある二つの結晶の体積比（または すべり量）は未知の量である. 現象論ではこの未知の量 や $\boldsymbol{R}$ は, $\boldsymbol{A}$ が不変面変形を表すように決尘され, その 結果として昆癖面方位, 双晶体積比, マルテンサイトと 甘相との方位関係などが求まる.

筆者らはこの現象論を小変形理論で記述することを試 みた ${ }^{12) 13)}$. 小変形理論とは，おのおのの行列から単位。 行列を引いた残りの行列を考えて, 変形や回転の組今せ を行列の和の形で表すものである，すなわち，歪みの二 次以上の高次項を無視した, 大変形理論の近似に相当す る.行列の積は一般には不可換であるが利は可換なので, 計算がずっと楽になる. 小変形理論によると $(4)$ 式は

$$
\boldsymbol{A}^{s}=\boldsymbol{R}^{s}+\boldsymbol{B}^{s}+\boldsymbol{P}^{s}
$$

と表される.ここで，たとえば $A^{S}=\boldsymbol{A}-\boldsymbol{I}$ (他も同様) である。

$\boldsymbol{A}$ が ( 3 )式で与えられるとき， $\boldsymbol{A}^{S}$ は次式のようにな る.

$$
\begin{aligned}
\boldsymbol{A}^{S} & =\left(\begin{array}{ccc}
0 & 0 & A_{13} \\
0 & 0 & A_{23} \\
0 & 0 & A_{33}
\end{array}\right) \\
& =\left(\begin{array}{ccl}
0 & 0 & A_{13} / 2 \\
0 & 0 & A_{23} / 2 \\
A_{13} / 2 & A_{23} / 2 & A_{33}
\end{array}\right)
\end{aligned}
$$

$$
+\left(\begin{array}{ccc}
0 & 0 & A_{13} / 2 \\
0 & 0 & A_{23} / 2 \\
-A_{13} / 2 & -A_{23} / 2 & 0
\end{array}\right) \quad \cdots \cdots \cdots \cdots(6)
$$

ここで，第三辺の第一項（対称行列）は歪みを，第二...項 （仅対称行列）は回転を表す。第一俱からわかるように， $x_{3}$ 面に対する無企み酒条件は, 歪み行列成分のうち 11 , 12，22 の备成分がゼロになるとき満たされる．さらに， 第…項を対角化すればわかるが，三つの主軸症みのうち 一つは正，一つはゼロ，残りの一つは傊のときのみに無 歪み面条件が満たされる ${ }^{12)}$. 大変形理論でもこれに相 当する無歪み阳条件が議論されている ${ }^{14)}$. 小変形弾性 論に基づくESHEI.BY の棈H体介在物理論 ${ }^{15)}$ を適用すれ ば，この無歪み面条件が満たされるとき，板状マルテン サイトが生成しても弾性エネルギーがゼロとなることが 示される 16)17). すなわち, 現象論の解析で求まるマル テンサイトの形態は弾性エネルギーに関しては最も都令 の良いものになっていることが，小変形理論を使うとよ くわかる.また，これが $r=1$ で記述される不変面界面 が好都合な界酒であることの物理的な意味である。

大変形理論に基づくオリジナルな現象論では, 晶癖面 方位やマルテンサイトと性との方位関係などの解を求 めるためには，コンピューター計算が不叮欠である。 方, 小変形理論を使えば, これらの解を簡単な解析解 として手計算で得ることができる. 例として, f.c.c. $\rightarrow$ b. c. c. マルテンサイト変態を考える ${ }^{12)}$. 格子対忠とし て通常のBain 対忍を採用する。すなわち, 渓 2 に示す ように, f. c. c. の $(h k l)_{f}$ 面と b. c. c. の $(p q r)_{b}$ 面(下 つきの $f$ と $b$ は, それぞれ f. c. c. と b. c. c. を表す) は

$$
(p q r)_{b}=(h k l)_{f}\left(\begin{array}{ccc}
1 / 2 & 1 / 2 & 0 \\
-1 / 2 & 1 / 2 & 0 \\
0 & 0 & 1
\end{array}\right)
$$

のようにまた, $[a b c]_{f}$ 㭣と $[u v w]_{b}$ 方问は

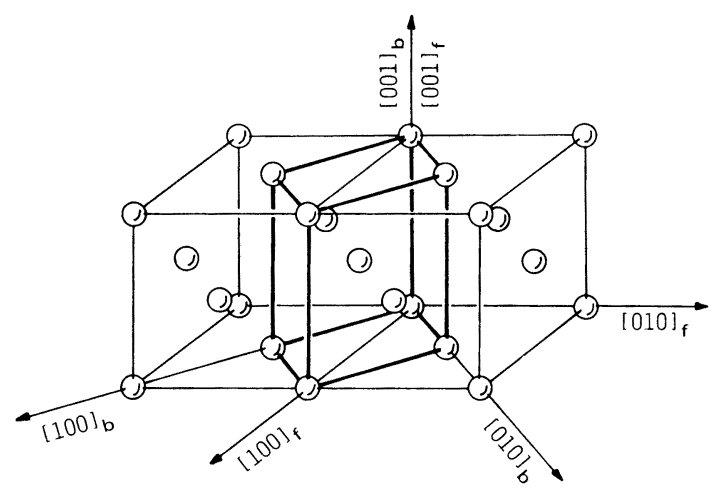

㲸 2 Bain 対忍 


$$
\left[\begin{array}{l}
u \\
v \\
w
\end{array}\right]_{b}=\left(\begin{array}{ccc}
1 & -1 & 0 \\
1 & 1 & 0 \\
0 & 0 & 1
\end{array}\right)\left[\begin{array}{l}
a \\
b \\
c
\end{array}\right]_{f}
$$

のようにBain 対忍すると考える.このとき, 格子変形 を表す行列 $\boldsymbol{B}^{S}$ は Bain 変形として

$$
\boldsymbol{B}^{s}=\left(\begin{array}{ccc}
\varepsilon_{1} & 0 & 0 \\
0 & \varepsilon_{1} & 0 \\
0 & 0 & \varepsilon_{2}
\end{array}\right)
$$

と書ける。（９)式では坐標系はf. c. c. 泚相の三つの主 軸に平行，すなわち， $x_{1} / /[100]_{f}, x_{2} / /[010]_{f}, x_{3} / /[001]_{f}$ にとってある.また， b. c. c. マルテンサイトと f. c. c. 甘相の格子定数をそれぞれ $a_{b}, a_{f}$ とすると, Bain 変形 の主軸歪みは, $\varepsilon_{1}=\sqrt{2}\left(a_{b} / a_{f}\right)-1, \varepsilon_{2}=\left(a_{b} / a_{f}\right)-1$ と表される。オリジナルな現象論と同様に，格子不変変 形 $\boldsymbol{P}^{S}$ として奶相での $(011)_{f}[0 \overline{1} 1]_{f}$ 双晶系 (マルテン サイト内での (112) $b[111]_{b}$ 双唱系に対忍する)を採用 して小変形理論の解析を行うと, 結晶学的に等価な解の 一つとして, 表 1 のような簡単な解析解が得られる ${ }^{12)}$. この解析解を見ると， $\varepsilon_{1}, \varepsilon_{2}$ が変化したときにマルテ ンサイトの結晶学がどのように変わるのかがすぐにわか るので，たいへん便利である。

小変形理論は大変形理論の近似なので, 表 1 の解は大 変形理論で得られる解と $\varepsilon_{1}, \varepsilon_{2} \rightarrow 0$ の極限で一致すべき

\begin{tabular}{|c|c|}
\hline 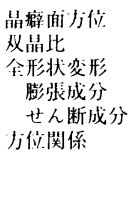 & $\begin{array}{l}\left(\left|-\varepsilon_{1} / \varepsilon_{2}\right|^{1 / 2},\left[\left|\varepsilon_{1}+\varepsilon_{2}\right| / \varepsilon_{2}\right]^{1 / 2}, 0\right)_{f} \\
\left|\varepsilon_{1}\right|:\left|\varepsilon_{2}\right| \\
2 \varepsilon_{1}+\varepsilon_{2} \\
-2 \varepsilon_{1}\left[-\left(\varepsilon_{1}+\varepsilon_{2}\right) / \varepsilon_{1}\right]^{1 / 2} \\
{[100]_{f} \wedge[110]_{b}\left[-\varepsilon_{1}\left(\varepsilon_{1}+\varepsilon_{2}\right)\right]^{1 / 2}} \\
{[010]_{f} \wedge[110]_{b}\left(-\varepsilon_{1} \varepsilon_{2}\right)^{1 / 2}} \\
{[001]_{f} \wedge[001]_{b}\left|\varepsilon_{1}\right|}\end{array}$ \\
\hline
\end{tabular}

\section{表 1 小変形理論の現象論で得られる解}

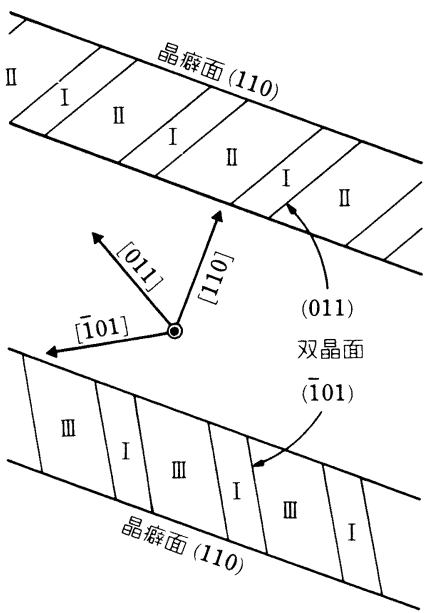

(a)

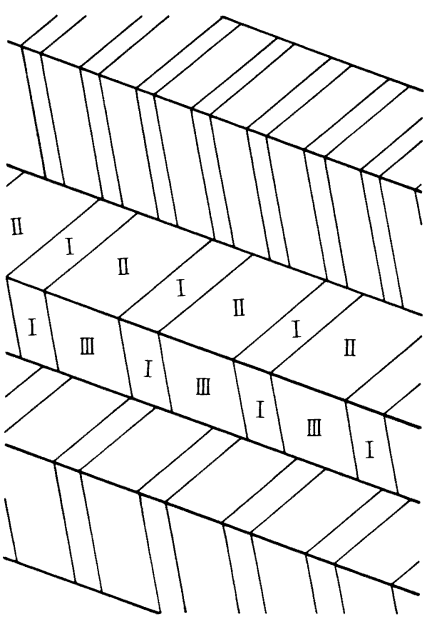

(b)
ものである．したがって，小変形理論で得られる解は， 格子変形歪み $\varepsilon_{1}, \varepsilon_{2}$ の大きさのオーダー $(\Delta$ とする $)$ の 相対誤差をもつことになる．すなわち，鉄合金の f. c. c. $\rightarrow$ b. c. c. (b. c. t.) マルテンサイト変態 $(\Delta \sim 0.1)$ では, たとえば晶癖面方位で $10^{\circ}(0.1 \mathrm{rad}$ のオーダー) 程度の 誤差があることになるが，ジルコニア合金の立方晶 $\rightarrow$ 正 方晶変態 $(\Delta \sim 0.01)$ では, この䛊差はせいぜい $1^{\circ}$ 程度 でかなり良い近似になっている12).

小変形理論の解を用いて,特別な場合を考えてみよう. もし，変態に伴う体積変化がゼロ，すなわち $2 \varepsilon_{1}+\varepsilon_{2}$ $=0$ ならば, 表 1 より晶澼面方位は (110), 双晶体積比 は $1: 2$ という簡単な解となる。この解で表される二つ の結晶学的に等価な板状マルテンサイトの形態を図 3 （a）に示す．この二つのマルテンサイト板が交互に重 なってできる形態を図 3 （b）に示す。この形態は前述 のように，変態に伴う弾性エネルギーを最小にする都合 の良いものの組合せで空間を埋めつくしたもので，マル テンサイト組織以外にも誘電体材料のドメイン構造 ${ }^{18)}$ などに見られる，特に，ジルコニア合金ではヘリング ボーン構造と呼ばれている19) 21).

以上のように，マルテンサイト変態の現象論を小変形 理論で記述すると, 見通しの良い解析解を得ることがで きるので，これをうまく利用すれば非常に便利である. 筆者らはもっと複雑な立方晶 $\rightarrow$ 単斜晶変態に対しても小 変形理論による解析的な計算を行い, $\mathrm{TiNi}$ 合金やジル コニア合金のマルテンサイト変態の結晶学を議論し た ${ }^{13)}$. その結果, 得られた解析解は大変形理論に基づ くコンピューター計算結果と非常に良く一致することを 確認している. （a）共通の晶癖面をもつ二つの等価な解

(b) 等価な解の交西の重ね合わせ

図 $32 \varepsilon_{2}+\varepsilon_{2}=0$ のとき小変形 理論解析で求まるマルテンサイト の形態 


\section{4. $r=2$ で記述される界面 (不変線変形)}

$r=2$ のときは ( 2 )式の連立方程式のうち独立な式が 二つあるので, 一般に $\boldsymbol{X}^{(O)}$ の解は直線を表す ${ }^{9)}$. I$A^{-1}$ の階数が 2 となるような行列 $\boldsymbol{A}$ は次式のような形 をしている.

$$
\boldsymbol{A}=\left(\begin{array}{ccc}
1 & A_{12} & A_{13} \\
0 & 1+A_{22} & A_{23} \\
0 & A_{32} & 1+A_{33}
\end{array}\right)
$$

この行列は $x_{1}$ 軸に平行な方向を不変線とする不変線変 形を表す．以下に示すように，不変線変形条件を界面の 結晶学に適用する場合は二次元問題となることが多い. そのときの $2 \times 2$ 行列 $\boldsymbol{A}$ は次式の形となる. ただし， この場合は $2 \times 2$ 行列である $\boldsymbol{I}-\boldsymbol{A}^{-1}$ の階数は 1 とな る.

$$
\boldsymbol{A}=\left(\begin{array}{cc}
1 & A_{12} \\
0 & 1+A_{22}
\end{array}\right)
$$

不変線変形が対象となる場合としては，基板結晶と蒸 着結晶の間の界面の問題が挙げられる。この場合は, 通 常与えられた面方位をもつ基板結晶の上に異種結晶の薄 膜を蒸着するので，問題は二次元となる．したがって， 三次元空間から自由に選べるマルテンサイトと母相との 界面とは異なり, 一般に不変面界面の形成は不可能であ る.しかし，次善の策として，不変線を含むような界面 形成は可能な場合がある.

二次元問題のときは, 大変形理論を使っても解析的な 議論が簡単にできる，今，基板結晶面と蒸着結晶面の間 に，ある格子対応を仮定すると，前者を後者に変換する 格子変形を表す行列 $\boldsymbol{D}$ は, (9)式と類似ではあるが二 次元大変形理論に基づいて次式のように書ける.

$$
\boldsymbol{D}=\left(\begin{array}{cc}
1+\varepsilon_{1} & 0 \\
0 & 1+\varepsilon_{2}
\end{array}\right)
$$

ここで, $\varepsilon_{1}, \varepsilon_{2}$ は格子対応と二つの結晶の格子定数で 決まる主軸歪みを意味する，眓 4 （a）のように，基板 結晶面を表す単位円領域 A は格子変形 $\boldsymbol{D}$ により, アス ペクト比が $\left(1+\varepsilon_{2}\right) /\left(1+\varepsilon_{1}\right)$ の蒸着結晶面を表す棈円 領域 $\mathrm{B}$ に変換される (ここでは $\varepsilon_{1}<\varepsilon_{2}$ としている).
これにより，円上のベクトル $V_{C}$ は棈川上のベクトル $V_{E}$ に変換されるが，润４（b）のように棈羏を円に対し て相対的に角度 $\theta$ だけ回転すれば，二つのべクトルは $V_{I}$ に一致し，この方们が变換前後で長さも方们も变わ らない不変線方向となる。 $\theta$ 回転は次のような行列 $\boldsymbol{R}$ で表される。

$$
\boldsymbol{R}=\left(\begin{array}{cc}
\cos \theta & -\sin \theta \\
\sin \theta & \cos \theta
\end{array}\right)
$$

したがって, 全変形を表す行列 $\boldsymbol{A}$ は

$$
\boldsymbol{A}=\boldsymbol{R D}
$$

と書ける.（4)式と比較すると，(14)式はマルテンサイ 卜変態の現象論の二次元版に対応していることが理解で きる．現象論での無歪み面条件に対忍して，ここでの不 変線存在条件は, 四 4 から明らかなように, $\varepsilon_{1}, \varepsilon_{2}$ のう ち一つは正，もう一つは傎となることである. DAHMEN は, $\operatorname{det}\left(I-A^{-1}\right)=0$ の条件より不変線条件を満たす $\theta$ が次のように表されることを導いた ${ }^{22)}$.

$\cos \theta=\left(1+\eta_{1} \eta_{2}\right) /\left(\eta_{1}+\eta_{2}\right)$

ここで, $\eta_{i}=1+\varepsilon_{i}(i=1,2)$ である. また，不変線べ クトル $V_{I}$ は成分表示で

$$
\boldsymbol{V}_{\boldsymbol{I}}=\left[ \pm \sqrt{\frac{\eta_{2}^{2}-1}{\eta_{2}{ }^{2}-\eta_{1}}}, \pm \sqrt{\frac{1-\eta_{1}^{2}}{\eta_{2}{ }^{2}-\eta_{1}{ }^{2}}}\right]
$$

となる ${ }^{23)}$.

実際に基板結晶/蒸着薄膜結晶系にどのようなエピ夕 キシャル方位関係が観察されるのかを調べるために, $\mathrm{Cu}$ と $\mathrm{Fe}$ のうち一方を基极結晶に，他方を蒸着結晶に

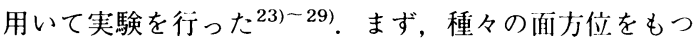
基板結晶の透過型電子顕微鏡 (TEM) 用試料を作製し, その上にもう一つの結晶を $10 〜 50 \mathrm{~nm}$ 程度蒸着した。 表 2 に種々の基板結晶面上に，TEM 観祭によって確認 された蒸着結晶の面方位をまとめて示す.これを見ると， 界面を形成する f. c. c. と b. c. c. の面は, 例外なく（7） 式の Bain 対応で結ばれていることがわかる.

界面方位がわかると，不变線条件を議論するための (12)式の $\boldsymbol{D}$ を次のように求めることができる.（7)式 より, 基板結昆 (f. c. c. とする) の $(h k l)_{f}$ 而は蒸着結昆 (b. c. c. とする) の $([h-k] / 2,[h+k] / 2, l)_{b}$ 面に

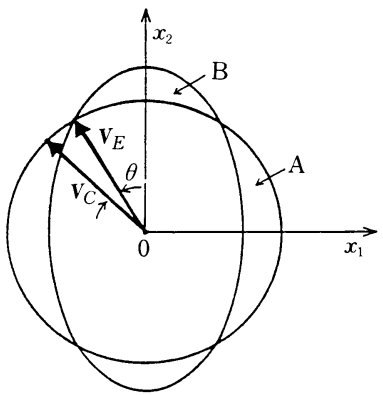

(a)

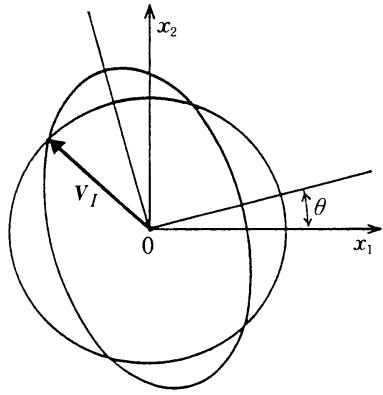

(b) (a) 神軸変形 $D$ (b) 问伝 $R$

㲸 4 不変線をもつ界面の形成 
表 $2 \mathrm{Cu} / \mathrm{Fe}(\mathrm{Cu}-\mathrm{Ni} / \mathrm{Fe})$ 系のエピタキシャル界面 の方位関係

\begin{tabular}{ll|ll}
\hline 基板結晶 & 蒸着結唱 & 基板結晶 & 蒸着結晶 \\
\hline $\mathrm{Cu}(001)$ & $\mathrm{Fe}(001)$ & $\mathrm{Cu}(012)$ & $\mathrm{Fe}(111)$ \\
& $\mathrm{Fe}(011)$ & & $\mathrm{Fe}(013)$ \\
$\mathrm{Cu}(011)$ & $\mathrm{Fe}(001)$ & $\mathrm{Fu}(013)$ & $\mathrm{Fe}(114)$ \\
$\mathrm{Cu}(111)$ & $\mathrm{Fe}(112)$ & & $\mathrm{Fe}(012)$ \\
$\mathrm{Cu}(112)$ & $\mathrm{Fe}(123)$ & & $\mathrm{Fe}(116)$ \\
$\mathrm{Cu}-\mathrm{Ni}(112)$ & $\mathrm{Fe}(012)$ & $\mathrm{Cu}(123)$ & $\mathrm{Fe}(122)$ \\
$\mathrm{Cu}(122)$ & $\mathrm{Fe}(134)$ & $\mathrm{Fe}(001)$ & $\mathrm{Fe}(136)$ \\
$\mathrm{Cu}(113)$ & $\mathrm{Fe}(012)$ & $\mathrm{Fe}(011)$ & $\mathrm{Cu}(001)$ \\
& $\mathrm{Fe}(013)$ & $\mathrm{Fe}(111)$ & $\mathrm{Cu}(111)$ \\
& $\mathrm{Fe}(112)$ & $\mathrm{Fe}(112)$ & $\mathrm{Cu}(011)$ \\
\hline
\end{tabular}

表 3 界面方位と主軸歪み方向の Bain 対応

\begin{tabular}{|c|c|}
\hline f. c. c. & b. c. c. \\
\hline$(h, k, l)_{f}$ & $([h-k] / 2,[h+k] / 2, l)_{b}$ \\
\hline $\begin{array}{l}\boldsymbol{x}_{1}^{f}=\left[h l, k l,-\left(h^{2}+k^{2}\right)\right]_{f} \\
\boldsymbol{x}_{2}=[-k, h, 0]_{f}\end{array}$ & 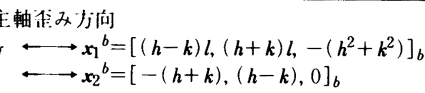 \\
\hline
\end{tabular}

Bain 対応して界面を形成するが，この二つの面上に互 いにBain 対応で結ばれ，しかも直交関係を保っている 二つの主軸歪み方向 $x_{1}{ }^{f}, x_{2}{ }^{f}$ (f. c. c. 面上) と $x_{1}{ }^{b}, x_{2}{ }^{b}$ （b. c. c. 面上）を一義的に表 3 に示すように求められる ことが証明できる ${ }^{23)}$. したがって, $\boldsymbol{D}$ の成分は次のよ うに表せる.

$$
\begin{aligned}
& 1+\varepsilon_{1}=\eta_{1}=\frac{\left|\boldsymbol{x}_{1}{ }^{b}\right| a_{b}}{\left|\boldsymbol{x}_{1}{ }^{f}\right| a_{f}} \\
& 1+\varepsilon_{2}=\eta_{2}=\frac{\left|\boldsymbol{x}_{2}{ }^{b}\right| a_{b}}{\left|\boldsymbol{x}_{2}{ }^{f}\right| a_{f}}
\end{aligned}
$$

ここで， $a_{b}, a_{f}$ はそれぞれ b. c. c. と f. c. c. の格子定数 である。これらがわかると，(15)，(16)式から不変線を 求めることができる. (なお， $\varepsilon_{1}$ と $\varepsilon_{2}$ が同符号のとき は不変線条件を満足しないが, そのときは便宜上 $\theta=$ $0^{\circ}$ となる界面が形成されると仮定する。)

基本的な例として， $\mathrm{Cu} の （ 111 ）$ ，基板面上に蒸着され た $\mathrm{Fe}$ 薄膜のエピタクシーを解析してみる. 表 3 から $(111)_{f}$ 面は $(011)_{b}$ 面に Bain 対応していることがわか る.また，おのおのの面上での二つの主軸方向は, $x_{1}{ }^{f}$ $=[11 \overline{2}]_{f}, \quad \boldsymbol{x}_{2}{ }^{f}=[\overline{1} 10]_{f}, \quad \boldsymbol{x}_{1}{ }^{b}=[02 \overline{2}]_{b}, \quad \boldsymbol{x}_{2}{ }^{b}=[\overline{2} 00]_{b}$ と 定まる. 今, $a_{f}=0.361 \mathrm{~nm}, a_{b}=0.286 \mathrm{~nm}$ とすると， (17), (18) 式より $\eta_{1}=(2 / \sqrt{3}) a_{b} / a_{f}=0.9148, \eta_{2}=$ $\sqrt{2} a_{b} / a_{f}=1.1204$ となるので, (15)式より $\theta=5.75^{\circ}$ を得る. 図 5 のように, $\theta=5.26^{\circ}$ のとき $\mathrm{KS}, \theta=0^{\circ}$ のとき NW の方位関係となる。したがって，不変線条 件で予測される $\mathrm{Cu}(111) / \mathrm{Fe}(011)$ 界面でのエピタキ シャル方位関係は, ほほ KS 関係であると言える. 実際, $\mathrm{Cu} / \mathrm{Fe}$ 系で $\mathrm{KS}$ 関係に近い方位関係が実験的に確認さ れている24)25). また, $a_{b} / a_{f}$ がわかれば $\theta$ の值がわかる ので, 不変線条件を使って, 種々の金属の組合せででき る $(111)_{f} /(011)_{b}$ 界面がどのような方位関係をとるのか を予測することができる。この予測法は手計算でできる 簡単な方法ではあるが，その結果は $\mathrm{O}$ 格子理論を用い た方法 ${ }^{5)}$, 模式図によるモアレ縞模様解析法 ${ }^{30)}$, 界面工 ネルギーのコンピューター計算に基づく方法 ${ }^{31)}$ などの, より複雑な方法で得られる結果と非常に良く一致してい $ろ^{32)}$.

Bain 対応と不変線条件を組み合わせれば，他の面方 位をもつ基板上で形成されるエピタクシーについても同 様の解析がすぐにできる。 そして，この予測法が実際に 観察された $\mathrm{Cu} / \mathrm{Fe}$ 系でのエピタキシャル方位関係を良 く説明することが示されている 23 ) 29).

ここで注意すべきことは, 基板面方位を一つ与えても， ( 7 )式の Bain 対応が一般には複数の界面候補を予測す るということである. その場合, どの界面候補が優先さ れて実際のエピタキシャル方位関係が決まるのかを知る 基準が必要になる. 筆者らはその基準として, 弾性エネ ルギーに近似的に比例する次式で定義される $M$ パラ

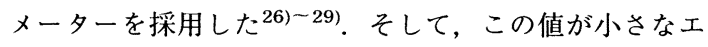
ピタクシーほど優先的に実現されると考えることによっ て，実験結果をうまく説明することができた．

$M=\varepsilon_{1}^{2}+\varepsilon_{2}^{2}+(2 / 3) \varepsilon_{1} \varepsilon_{2}$

ここで $\varepsilon_{1}, \varepsilon_{2}$ は $(17),(18)$ 式より求まる主軸歪みであ

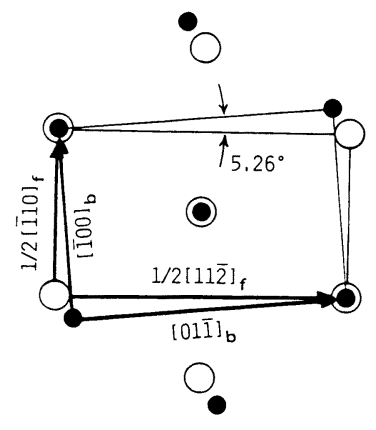

(a) KS
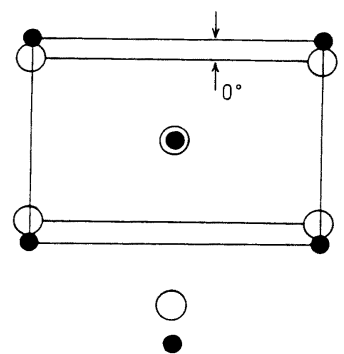

(b) NW $\bigcirc$ : f.c.c. 原子 : b.c.c. 原子

図 5 (a) KS と（b) NW の方位関係 
る、筆者らはさらにこの $M$ パラメーターを利用して, 各種立方晶結晶の (001) 面基板上に他の立方晶結晶を 蒸着したときに優先形成されるさまざまなエピタクシー を予測し, 実験事実と良く一致する結果を得ている ${ }^{33)}$.

以上のように, Bain 対応, 不変線条件, $M$ パラメーター の三つの因子を考えることによって，異相界面でのエピ タクシーを議論してきた。実は，このうちの Bain 対応 はf. c. c. /b. c. c. 界面で, しかも二つの結晶の原子同 士が $1: 1$ に対応するときのみに適用できるものであ る.これ以外の界面の場合は, 他の適当な格子対応を決 めなければ幾何学的な考察はできない。ところが, 一般 に格子対応は無数に考えられるので，どの対応が最も合 理的なものかを判断しなければならないことになる．紙 面の制約上詳しい説明はできないが，ZUR と MCGILLに よる“還元された超格子” (Reduced superlattice) の考 え方 ${ }^{34)}$ は，格子対志を決める際に有用なものである. 実際, Si の (001) 面上に蒸着された $\mathrm{Al}$ のエピタクシー を説明するために，この考え方がうまく利用されてい $ろ^{35)}$.

\section{5.おわりに}

高分解能電子顕微鏡による原子配列の直接観察法や, 固体物理学・量子化学の知識を駆使して界面構造を調べ る近代的な解析法が異相界面の研究にも盛んに用いられ ている現在，ここで概観した幾何学的な解析法などはい かにも古く思われるであろう。確かに幾何学的な考察に は限界があり，それでは説明できない界面の方がむしろ 多いことは十分承知しているつもりである. しかし，多 くの先達がすばらしいひらめきによって築き上げた美し い幾何学的理論が非常に明快に界面の結晶学を説明する ときに，驚愕と感嘆の念を覚えるのは筆者だけであろう か. 本拙文が幾何学的考察法の初歩を知るためのお役に 立てれば嬉しい.

\section{文献}

1 ) G. Kurdjumov and G. Sachs: Z. Phys., 64 (1930), p. 325

2 ) Z. Nishiyama: Sci. Rep. Tohoku Univ., 23 (1934), p. 638

3 ) G. Wassermann: Mitt. Kaiser-Wilhelm-Inst. Eisenforsch., 17 (1935), p. 149

4 ) 石田洋一: 日本金属学会会報, 22 (1983), p. 80

5 ) 橋本 敏: 日本金属学会会報, 22 (1983), p. 151

6 ) 大森靖也: 結晶界面一基礎から忍用まで一( H 本鉄鈎協会
編) (1990), p. 7

7 ) 根本 尧: 結昆然面一基礎から心用まで一(日本鉄銅協会 編) (1990), p. 27

8 ) 榎本正人, 古原 忠: 鉄と鎆, 77 (1991), p. 735

9 ) W. Bollmann: Phil. Mag., 16 (1967), p. 363, p. 383

10) M. S. Wechisler, D. S. Lieberman and T. A. Read: Trans. Metall. Soc. AIME, 197 (1953), p. 1503

11) J. S. Bowl.es and J. D. Mackfenzie: Acta Metall., 2 (1954), p. 129, p. 138, p. 224

12) M. Kato and M. Shibata-Yanagisawa: J. Mater. Sci., 25 (1990), p. 194

13) $M$. Shibata-Yanagisawa and $M$. Kato: Mater. Trans. JIM, 31 (1990), p. 18

14) D. S. Lieberman, $M$. S. Wechsler and T. A. Re.Aj: J. Appl. Phys., 26 (1955), p. 473

15) J. D. Eshel.bY: Proc. R. Soc., London, A241 (1957), p. 376, A252 (1959), p. 561

16) T. Mura, T. Mori and M. Kato: J. Mech. Phys. Solids, 24 (1976), p. 305

17) M. Kato, T. Miyazakı and Y. Sunaga: Scr. Metall., 11 (1977), p. 915

18) I. S. Zheludev: Modern Crystallography IV, ed. by L. A. Shuvalov (1988), p. 220 [Springer-Verlag]

19) T. Sakuma, $Y$. Yoshizawa and H. Suto: J. Mater. Sci., 20 (1985), p. 2399

20) $M$. Hayakawa, $M$. Talda, $H$. OKamoto and $M$. OKa: Trans. Jpn. Inst. Met., 27 (1986), p. 750

21) $M$. Shibata-Yanagisawa, $M$. Kato, $H$. Seto, $N$. Ishizawa, N. Mizutani and M. Kato: J. Am. Ceram. Soc., 70 (1987), p. 503

22) U. Dahmen: Acta Metall., 30 (1982), p. 63

23) M. Kato and T. Mishima: Phil. Mag. A, 56 (1987), p. 725

24) M. Kato, S. Fukase, A. Sato and T. Mori: Acta Metall., 7 (1986), p. 1179

25) M. Kato, S. Fukase, T. Mishima, A. Sato and T. MorI: Proc. Int. Conf. on Martensitic Transformations, The Japan Inst. Metals (1986), p. 343

26) M. Kato, T. Kubo and T. Mori: Acta Metall., 36 (1988), p. 2071

27) $M$. Kato, $M$. Wada, $M$. Shibata-Yanagisawa and $T$. Mori: Colloq. Phys., 51 (1990), p. C1-849

28）井上畺望: 東京I業大学修士論文 (1991)

29）洔前智: 東京上業大学卒業論文 (1991)

30) L. A. Bruce and H. Jaegar: Phil. Mag. A, 38 (1978), p. 223

31) 後藤芳彦, 福田 博: H本金禹学会会報, 29 (1990), p. 219

32) M. Kato: Mater. Sci. Engng., A146 (1991), p. 205

33) M. Kato, M. WadA, A. Sato and T. Mori: Acta Metall., 37 (1989), p. 749

34) A. Zur and T. C. McGll..: J. Appl. Phys., 55 (1984), p. 378

35) M. Kato and H. Niwa: Phil. Mag. B, 64 (1991), p. 317 